\title{
Essays
}

\section{On Teaching Rape: Reasons, Risks, and Rewards}

\author{
James J. Tomkovicz ${ }^{\dagger}$
}

Law school classrooms are by nature places of contention and dispute. Ordinarily, the arguments are controlled and abstract, but when certain controversial topics are the focus of the day, the clashes can be characterized by depths of feeling and tensions well beyond the norm. The visible dynamic on such days masks a number of other dynamics between the students and the instructor, and among the students themselves. Usually, the forces operating below the surface go unrecognized or, at least, unacknowledged. My recent experience teaching rape law for the first time provided me with the inspiration and the occasion to disclose, describe, and discuss-from a professor's vantage point-the pressures, motivations, and decisions that surface when a criminal law class takes up one of the more controversial and divisive issues of our times.

\section{PAST}

\section{A. Prelude and Preparation}

I have taught a first-year course in substantive criminal law since 1982. From the start, I have used a casebook that focuses not on particular crimes ${ }^{1}$ but on

$\dagger$ Professor of Law, University of Iowa College of Law; Visiting Professor of Law, 1992, University of Michigan School of Law. B.A. 1973, University of Southern California; J.D. 1976, UCLA School of Law. I am grateful to my wife, Nancy, and to my colleague, Welsh White, for giving me the encouragement that was needed when I first thought of writing this piece. Ken Duker deserves credit for his able research assistance.

1. The text is SANFord H. KADISH \& STEPHEN J. SCHUlHOFER, CRIMNAL LAW AND ITS PROCESSES 
general themes. ${ }^{2}$ I consider such a focus to be proper for a basic course at a quality law school that aspires to educate law students with the potential to rethink and reshape our legal system. ${ }^{3}$ Consequently, it never would have occurred to me that I was somehow derelict or irresponsible in failing to address any particular category of crime. Sometime in the mid-to-late 1980's, however, society's increasing concern with sexual assaults, ${ }^{4}$ coupled with a perception that the legal system's treatment of the subject was sorely in need of reform, gave rise to the complaint that criminal law casebooks and criminal law professors (who were predominantly male) were guilty of neglecting the subject. ${ }^{5}$ I choose the word "guilty" intentionally because the message that I heard was that the omission of rape from the introductory study of criminal law was wrongful, cowardly, and symptomatic of society's refusal to come to grips with rape and other issues involving the victimization of women. ${ }^{6}$

(5th ed. 1989) [hereinafter KADISH \& SCHULHOFER]. Most, if not all, criminal law casebooks are designed to teach general criminal law themes rather than the elements of specific crimes.

2. Chapter headings in the Kadish and Schulhofer text, id., such as How Guilt is Established, The Justification of Punishment, and Exculpation, illustrate the point. Prior to the addition in the late 1980's of the chapter called Rape, only one chapter that I had never taught, Theft Offenses, was devoted to a specific crime. Although various homicidal offenses are the subjects of subsections of the Homicide chapter, the general aims of that chapter are to explore the distinction between criminal and noncriminal homicides and to examine issues of gradation.

3. See KADISH \& SCHULHOFER, supra note 1, at xxxi (stating that casebook focuses on "basic principles and doctrines that come into play across the range of specific offenses" and that "mastery of the detailed elements of many particular crimes is a goal that is inappropriate for a basic criminal law course"); WAYNE R. LAFAVE \& AUSTIN W. SCOTT, JR., CRIMINAL LAW xvii (2d ed. 1986) (stating that "[t]he imparting of detailed information about many different crimes is not the goal of a basic course in criminal law").

4. The terms "rape" and "sexual assault" are not necessarily synonymous. Many, myself included, typically use "rape" to refer to the most serious and egregious forms of sexual assault. For purposes of this essay, however, the terms are interchangeable.

5. I do not recall when or how I first became aware of this complaint. As early as 1972 Professor Barbara Babcock pointed out that "only one of the four leading criminal law casebooks ... covered rape as a separate substantive crime." Nancy S. Erickson \& Nadine Taub, Final Report: "Sex Bias in the Teaching of Criminal Law," 42 RUTGERS L. REV. 309, 344 (1990). In 1986, Professor Nancy Erickson observed that traditional casebooks evidenced a "subtle type of sex bias" by their "failure to include, or superficial coverage of, issues of particular concern to women." Nancy S. Erickson, Legal Education: The Last Academic Bastion of Sex Bias? 10 NovA L.J. 457, 458 (1986) [hereinafter Erickson, Legal Education]; see also Erickson \& Taub, supra, at 316-17; Nancy S. Erickson, Sex Bias in Law School Courses: Some Common Issues, 38 J. LEGAL EDuc. 101, 104-05, 115 (1988) [hereinafter Erickson, Sex Bias].

Fifteen years after Professor Babcock's initial expression of concern about the omission of rape from criminal law casebooks, Professors Erickson and Taub "found progress in terms of pure coverage." Of the seven casebooks they reviewed, five "include rape as a separate substantive crime." Erickson \& Taub, supra, at 345 .

6. The language in the articles documenting the omission of rape from criminal law texts unmistakably suggests that those who neglect to teach subjects such as rape are not fulfilling their responsibilities. See Mary Irene Coombs, Crime in the Stacks, or A Tale of a Text: A Feminist Response to a Criminal Law Textbook, $38 \mathrm{~J}$. LEGAL EDUC. 117, $118 \mathrm{n} .9$ (1988) (referring to "inadequacies of most casebooks in dealing with gender-related issues" as "legion"); Erickson \& Taub, supra note 5, at 316-17 (referring to "[s]ex bias in traditional casebooks"); id. at 344-45 (claiming that omissions of rape "can be viewed as an assessment of the crime's importance"); id. at 350-51 (warning that "a superficial treatment" of rape law "can be both misleading and offensive"); Erickson, Legal Education, supra note 5, at 458 (stating that "casebook authors can always rationalize lack of coverage on various grounds"); Erickson, Sex Bias, supra note 5, at 105 (suggesting that when "a topic of particular concern to women" is covered superficiaily, "one may infer that the author is denigrating the topic's importance"). 
In 1989 the authors of my preferred text published a new edition. They, too, had heard the complaints and had responded with a separate chapter entitled Rape. ${ }^{7}$ One might expect that such a noticeable change in my primary teaching tool would have forced me to consider closely the appropriateness of teaching the law of rape. I confess that it did not. I do not even remember whether I gave more than passing attention to the issue. I am sure that I never seriously contemplated adding the chapter to my syllabus.

During the few years that the chapter has been in the text, a handful of students not only noticed that the course syllabus bypassed Chapter Four but were both curious and brave enough to ask me (always privately) why we skipped over rape. ${ }^{8}$ My answer was always essentially the same and the students always seemed satisfied with it:

I've been teaching this course since long before the rape chapter entered the book. All of the hours in the semester are filled with other important, more general subjects. As it is, we are barely able to discuss them adequately in the very limited time we have. Were $I$ to add rape, another subject would have to be deleted-a subject of probably greater importance for students of introductory criminal law. I do not believe there is a legitimate reason to do so. In addition, we do not study any crimes per se in this course. To study rape would be to accord it a sort of special status that I have not been persuaded is justified.

On reflection, I am surprised students accepted this reply so readily. While it was always honest, it was never complete. One unspoken premise was that I harbored a certain amount of resentment toward "right thinkers" who presumed to tell me what I should or must teach. Unlike the authors of the casebook, I was not going to kowtow to any interest group; I was not going to be blown off course by the winds of a transient movement. ${ }^{9}$ I would change my approach when I was convinced that there was tangible educational benefit . . . and not a moment before. My answer was also incomplete-some might say dishonest-because I did not admit that I had not really examined the question. I had not considered the arguments in favor of including rape law, nor had I even read the chapter that had been added to the text. I had effectively put the burden on others to persuade me that the subject was important enough to be

7. The explanation for adding Rape found in the Preface to the Fifth Edition is exceedingly brief. According to the authors, "[ $t]$ he chapter on rape provides an opportunity to focus on the definitional elements of a major crime in a context that has become the focus of acute controversy because of changing perceptions and changing social values." KADISH \& SCHULHOFER, supra note 1 , at xxxi. They note that the chapter "is important in its own right and as a complement to the materials on mens rea." Id. at xxxii.

8. I should note that rape is not the only significant subject I ordinarily omit. With the exception of a single inquiry regarding the failure to cover the death penalty, none of the other omissions has ever been questioned.

9. Suspicion of the authors' motives was my attitude at the time. Today I would not accuse them of caving in to pressure from interest groups. Equipped with a new awareness of the benefits of teaching rape law, I find their assessment of the virtues of a chapter devoted to sexual assault to be highly credible. 
included in the semester's work. Needless to say, the likelihood of someone doing so and overcoming my suspicions about his or her motives was quite small. The status quo was comfortable; inertia seemed destined to prevail.

Despite increasing age and experience, I continue to be surprised that change often approaches stealthily and from an unexpected direction. In this case, it concealed itself behind an invitation to become a visiting professor at the University of Michigan School of Law, extended in the spring of 1991 and quickly accepted. When I learned that Michigan's criminal law course was allotted four semester hours rather than three, as at lowa, I decided to add two topics to my course: the limits of criminalization ${ }^{10}$ and rape. The initial decision to include rape was easy; it never crossed my mind that I should avoid the subject because it might be too hot to handle. The minor apprehension I had was rooted in simple indolence - I would have to spend a lot of time preparing this new unit in a course that I could otherwise teach in my sleep.

Not once as I prepared the syllabus, read Chapter Four for the first time, mentioned my decision to colleagues at Iowa, and began to think about the subject in depth did I anticipate any of the dangers implicit in my choice. It is difficult to believe that I could have been so oblivious, but I may have been blinded by the challenge and emboldened by a subconscious sense that little could go wrong because, after all, I was doing the "right" thing.

Perhaps one explanation for my unqualified commitment to take the plunge was the remarkable timeliness of the topic. This was a year in which the victimization of women had assumed center stage on our national theater. The Thomas-Hill hearings in October of 1991, the William Kennedy Smith trial in November, and the impending Mike Tyson rape prosecution in early 1992 had brought general issues of male oppression-and the specific issue of criminal sexual assault - to the forefront of our social consciousness. What better context for an initial foray into the law of rape? Real cases, concrete issues, prominent people, and the mysteries of our adversary system were on display in ways that highlighted the vitality and the importance of the various debates. My choice seemed all the more sensible and challenging as the days passed.

On day one of my visiting appointment, during the opening minutes of an introductory lecture, I passed the point of no return in two distinct ways. From the podium I declared that the additional hours Michigan allocated to criminal law had provided me with an opportunity and that we all would be the beneficiaries. I announced that I had not taught rape at Iowa-intimating that I had valid reasons that I would divulge privately if anyone cared to learn-but that we would be addressing the subject. In addition, the syllabus that was passing through the class confirmed my intention in writing. Had the inclination not

10. The reference is to concerns that play a role in deciding whether a particular type of conduct should be brought within the coercive sphere of the criminal law. This subject also has the potential for controversy. The main case presented in the text is Bowers v. Hardwick, 478 U.S. 186 (1986), in which the Supreme Court held that criminalization of consensual homosexual sodomy is constitutional. 
to discuss rape arisen after that point, I would have been hard pressed to produce a credible explanation.

During the first few weeks of the semester I spent many hours doing preparatory reading. I knew little about the issues that would arise in the study of sexual assault. I reread the material in the casebook and studied Susan Estrich's Real Rape. ${ }^{11}$ Professor Estrich's book dealt with several of the cases presented in the casebook and seemed to treat the basic social and legal issues engendered by the criminalization of sexual assault. It left me much better equipped, but I still felt that I lacked a complete, logically ordered understanding of the past and current law and issues. For basics, I turned to the preeminent hornbook on criminal law, ${ }^{12}$ but to my dismay this ordinarily reliable tool for foundational study did not have an apposite chapter or section. ${ }^{13} \mathrm{~A}$ brief search led me to the Comments to the Model Penal Code ${ }^{14}$ where I found a comprehensive and thoughtful treatment of the law's origins and historical development, the contemporary concerns that have prompted cries for change, and the variety of legal approaches to resolving old and new questions. The Comments assisted me in the development of an analytic framework into which I could fit various matters that had seemed to lack structure. I began to feel that I had a more than superficial appreciation of the law of rape and the policy choices involved in the criminalization of sexual assaults.

I began to sense that our study of sexual assault would not seem an anomalous departure from the focus upon overarching criminal law concerns. Instead, the topic would be a vehicle for contributing to student understanding of fundamental themes. One concept that we could revisit was the appropriate boundaries of criminalization-how to decide where to fix the line between the immoral or undesirable and the criminal. Another was the theoretical and practical difficulty of defining precisely the acts that one wishes to criminalize. A third theme was gradation-whether there should be multiple degrees of sexual assault and, if so, what criteria should define the categories. The only trepidation I had as Chapter Four approached was that born of the insecurity involved in teaching any subject for the first time.

11. SUSAN ESTRICH, REAL RAPE (1987).

12. LAFAVE \& SCOTT, supra note 3 .

13. Id. In his preface, Professor LaFave does not specifically address the omission of rape. He does provide a general explanation for omitting a detailed treatment of most crimes from the text:

[T] his text is not an encyclopedia of crimes in which black-letter definitions of all common offenses-from abortion to vagrancy - may be found. The imparting of detailed information about many different crimes is not the goal of a basic course in criminal law, and thus the discussion of specific offenses herein is limited to certain crimes against the person ... and crimes relating to property. ...

Id. at xvii. LaFave explains that "[m]ajor emphasis is given to homicide and theft" because they are "particularly suited" to the teaching and leaming of certain general themes and principles. Id. The omission of rape law from this textbook has been criticized for "suggest[ing] by implication that rape is not an important enough crime to be on the select list of those included." Coombs, supra note 6, at 122 .

14. MODEL PENAL CODE $\S \S 213.0-213.6$ (A.L.I. 1980). 
It crossed my mind that I might encounter an extremist with an agenda reflective of one or the other end of the philosophical-political spectrum and that such an individual might challenge me in a way that would be difficult to handle, but I did not live in fear and dread of classroom confrontation. ${ }^{15}$ I was relatively confident that a nonopinionated, balanced, open approach to the subject coupled with my usual proclivity for challenging every viewpoint and argument would avoid undue controversy and contention. Moreover, I was prepared to terminate any discussion that threatened to degenerate into an emotional battle or personal invective.

\section{B. Teaching Rape}

To some, my prelude might imply the imminence of a deserved comeuppance and an excruciating learning process for an experienced law teacher who approached a volatile area with far too much naivete and confidence. In reality, there were few fireworks. The week was an educational success that taught me a great deal about the real reasons to teach or not to teach the law of rape, and my troops and I emerged from the experience with but a handful of battle scars.

We reached the rape law unit early in the fifth week of classes. I introduced the topic by referring to some recent newspaper stories, including one concerning the Mike Tyson trial that had just begun. ${ }^{16}$ My aim was to convey two impressions: that the crime of sexual assault is prevalent and that the topic is one of profound public interest and concern. Lest the reader conclude that I was unaware of possible pitfalls, I should add that I began the discussion in an unusual way. I acknowledged up front that rape is a sensitive and controversial subject. I asked students to be a bit more thoughtful and careful in expressing their views in the hope that we could avoid unnecessary offense to any members of the class, and suggested that people should think more than once or twice before phrasing a position in a particular way. I then added that I certainly did not intend to suggest that only "politically correct" positions would be tolerated, or to stifle any legitimate debate, but instead wanted a robust, open discussion that included all viewpoints. My goals were to keep the discussion above the personal level and to avoid unnecessary emotional injuries. In this area, an ounce of prevention seemed well worth a pound of cure. ${ }^{17}$

As I do with some other topics, I began the rape discussion by asking an open-ended question designed to ascertain preconceptions and views unaffected

15. Later, one of the students apprised me that as we had approached the chapter on rape she had become intensely fearful of an explosive and destructive classroom discussion. Her experiences with discussions of abortion and race during her section's constitutional law course had made her painfully aware of the potential for excessively emotional debate and inappropriate personal attacks. at $1 \mathrm{~A}$.

16. E. R. Shipp, Rape Was Like Game to Tyson, Woman Testifies, DETROTT FrEE PREss, Jan. 31, 1992,

17. See Erickson, Sex Bias, supra note 5, at 114 (suggesting professors might take "the offensive" to avoid classroom problems growing out of teaching rape law). 
by immersion in the law. ${ }^{18}$ I inquired of the class how they would, if they could, define the category of behavior to be criminalized as rape. This query was met with deafening, uncomfortable silence from all in attendance. After some prodding, a student, Ms. R, volunteered the proposal that nonconsensual sexual intercourse should be considered rape. There followed a constructive inquiry into what she meant by consent, how silence would be treated, whether verbal refusal followed by persuasion and agreement would be acceptable, how long an expression of nonconsent would be effective, and related matters. I felt that we had made an excellent start.

As we moved on to treat the specific issues raised by the cases and notes, I promised that we would return later to the questions raised by Ms. R's proposed definition of rape. For four days we explored all of the traditional issues concerning the definition of the actus reus components, occasionally addressed mens rea issues, ${ }^{19}$ gained some insights into the interrelationship of those two fundamental components, and even considered a few problems of evidence. Throughout the discussion, the classroom atmosphere remained professional. Although strong feelings clearly motivated some of the comments, the environment never became highly charged, and no disagreements even approached the bounds of propriety.

At the end of the third class session, we considered actual statutory formulations that declare sexual intercourse without consent to be criminal. ${ }^{20}$ Once again, we discussed the meaning of consent and the advisability of defining the crime by focusing on the victim's state of mind. I recall closing that class session-the final one of the week-by describing an Iowa colleague's suggestion that consent be defined to require written consent. A skeptical look came over many of the faces in class that day. I indicated that we would return to that proposal on the following Monday, and that students should be prepared

18. I have used this approach to introduce the rights to counsel, to jury trial, and to a speedy trial, and the protection against double jeopardy, for example. Frequently, students accept basic constitutional guarantees without any sense of their underlying values. My questions are intended to inform both them and me of the level of their appreciation of such values.

19. The main mens rea issue in rape is what state of mind, if any, must be proven with regard to the nonconsensual nature of the intercourse. Three possibilities emerge: strict liability, which makes an accused's mistaken belief about consent irrelevant; negligence, which makes a "reasonable" belief exculpatory; and recklessness or knowledge, both of which make an honestly held belief a defense.

20. See, e.g., DEL. CODE ANN. tit. 11, \$773 (1987) ("A person is guilty of unlawful sexual intercourse in the third degree when he intentionally engages in sexual intercourse with another person and ... [t] intercourse occurs without the victim's consent"); WASH. REV. CODE ANN. § 9A.44.060 (West 1988) (rape in the third degree is committed when "the victim did not consent . . . to sexual intercourse with the perpetrator and such lack of consent was clearly expressed by the victim's words or conduct"); WIS. STAT. ANN. $\$ 940.225(3)$ (West 1982) (defining third-degree sexual assault as "sexual intercourse with a person without the consent of that person"). These laws matched the proposal by Ms. $R$ that had launched our discussion of rape law. It was fitting to return to the topic and discover that no jurisdiction defines the most serious category of sexual assault simply in terms of the lack of consent. 
to comment, praise, or criticize. I stayed after class for some time discussing the idea with interested students.

An episode that occurred outside the classroom then made me wonder whether I should avoid returning to the written consent proposal the following Monday. When I had mentioned the idea to an acquaintance within the law school, her response had devolved rapidly into what seemed to be personal hostility premised on a serious misunderstanding of my position. I had come away from the encounter with a great deal of frustration, defensiveness, and inner turmoil. Nonetheless, I decided that the potential educational value of discussing the proposal offset the risks. If both those who were interested in protecting women from sexual assault and those who believed that modern trends have unfairly slanted the law against accused men might find the idea unpalatable, clearly this proposal could stimulate productive debate. Besides, my students had not yet shown any inclination toward personalization or intolerance.

The decision proved sound. The discussion was constructive and temperate. After thoroughly exploring the proposal, we turned to the final substantive issue, the traditional exemption of husbands from prosecution for rape. I raised a hypothetical, and, by placing it in two different jurisdictions (Michigan ${ }^{21}$ and a Model Penal Code ${ }^{22}$ state), illustrated dramatically different legal outcomes for an accused husband. I then pointed out that Michigan's law had been changed to eliminate the marital rape exemption a mere three-and-one-half years earlier. ${ }^{23}$ Confident that not a single student would choose to defend the spousal exemption, I sought to "hire" a student to lobby the legislature with modern reasons to reinstate the exemption. I chose a bright young woman, a product of the Ivy League. She balked at her assigned role, seemingly unclear on the nature of her task. When I pressed her to suggest reasons that might persuade a contemporary legislature to adopt a spousal exclusion, she offered the thought that women were viewed by some as the property of their husbands. Playing legislator, I called the idea antiquated. She then asked whether I wanted her to furnish contemporary justifications for "allowing a husband to rape his wife." Playing client, I suggested that I might not want to hire an advocate who was going to concede the issue in the way she phrased her arguments. Finally, two other students cautiously volunteered to help out. Both first distanced themselves from the ideas they were about to express by announcing that they did not agree with the spousal exemption or the arguments that are thought to justify it. They

21. MiCH. COMP. LAWS ANN. $\$ 750.520 l$ (West 1988) (“A person may be charged and convicted ... even though the victim is his or her legal spouse.").

22. MODEL PENAL CODE $\$ 213.1$ ("A male who has sexual intercourse with a female not his wife is guilty of rape if. ...").

23. Prior to its amendment in 1988, the Michigan Penal Code provided that "[a] person does not commit sexual assault under this act if the victim is his or her legal spouse, unless the couple is living apart and one of them has filed for separate maintenance or divorce." MICH. COMP. LAWS ANN., $\$ 750.520 l$ note. 
then proffered the "marriage preservation" and "difficulty of proof" rationales that the Model Penal Code commentary suggests. ${ }^{24}$ Had it not been for those two students, the class might not have heard the rationales for a position that dominated rape law until very recent times. ${ }^{25}$

On the last day of our discussion we debated two evidentiary matters, the now defunct requirement that a rape victim's testimony be corroborated and the modern emergence of "rape shield" laws. ${ }^{26}$ When I apologetically ended the discussion with fifteen minutes left in the hour, a number of disappointed students lowered their hands.

Because this was my first time teaching the law of sexual assault, I had prepared a brief summary of what I had learned from the experience. I regarded my reflections as neither profound nor controversial. My simple hope was that they might prompt students to focus on what they had learned. I indicated that the study of rape had given me a new appreciation of the difficulty of describing a line between criminal and noncriminal behavior. I revealed my realization that rape is in some ways a unique crime. ${ }^{27}$ More specifically, it is predominantly

\footnotetext{
24. MODEL PENAL CODE $\$ 213.1$ commentary at $344-46$.

25. Most of the scholarly sources I consulted suggest that the spousal exemption for forcible rape remains a majority position in American law. In fact, as of July 1989 laws in 42 states allowed prosecutions of husbands for raping their wives in at least some circumstances. DIANA E. H. RUSSELL, RAPE IN MARRIAGE 21, 23 (rev. ed. Ind. Univ. Press 1990) (1982). Four states have abolished the marital exemption since then. MO. REV. STAT. $\$ 566.085$ note (Vernon Supp. 1992) (noting that a 1991 amendment eliminated the spousal exemption); N.M. STAT. ANN. § 30-9-11 note, § 30-9-12 note (Michie Supp. 1991) (same); S.D. CoDIFIED LAWS ANN. \$ 22-22-1 note (Supp. 1992) (noting that a 1990 amendment eliminated the spousal exemption); UTAH CODE ANN. § 76-5-402(2) (Supp. 1992) (providing that crime of rape may be committed whether or not the actor and the victim are married). In 1980, prosecutions of husbands were possible in only eight states. RussEL, supra, at 21 . This enormous change in just one decade illustrates the rapidity with which modern views can supplant traditions in rape law.

It is increasingly the case that student distaste and fear hinder the development of all sides of a controversial issue such as the spousal exemption. Those who find an unpopular position attractive sometimes fear hostility. Those who do not agree with such a position sometimes refuse to explain it for fear that they might be associated with it. It is a shame that robust discussion is hampered by these realities of the modern classroom. A well-educated lawyer knows and is prepared to deal with the opposing side's arguments. See Alan M. Dershowitz, Political Correctness, Speech Codes \& Diversity, HARV. L. REC., Sept. 20, 1991, at 7 ("As a teacher, I can feel a palpable reluctance on the part of many students-particularly those with views in neither extreme and those who are anxious for peer acceptance-to experiment with unorthodox ideas, to make playful comments on serious subjects, to challenge politically correct views and to disagree with minority, feminist or gay perspectives. ... I worry about the impact of politically correct intolerance on the generation of leaders we are currently educating.").

26. In the past, the predominant requirement was that a victim's testimony alleging rape be "corroborated" in some way. See KADISH \& SCHULHOFER, supra note 1, at 399-403. The gist of "rape-shield" statutes is the protection of sexual assault victims against unwarranted exploration of their past sexual conduct. In discussing the latter subject, I juxtaposed the question of using an accused man's past behavior to prove the charged incident. This issue came to the forefront of the William Kennedy Smith trial when the judge ruled that three instances of past conduct that the prosecution wished to prove were insufficiently similar to be admissible. See David Margolick, Why Jury in Smith Case Never Heard from 3 Other Women, N.Y. TIMES, Dec. 13, 1991, at B14.

27. I realized that some might disagree with the idea that rape is unique among crimes, especially if they understood it as code for an approach that would suspend the normal safeguards in rape prosecutions. I endorsed no such approach, however, and felt it important to emphasize my sense of the uniqueness of rape.

Others, usually women, had stressed the special character of rape in past discussions with me. Some were bent upon radical reduction of the protections accorded accused rapists. Others were troubled by the
} 
a crime of male perpetrators and female victims, and there is (to borrow Professor Estrich's word) a "power" differential between men and women in our society. ${ }^{28}$ I suggested that while gender neutrality in statutory language might have symbolic significance, as a practical matter it would not have much impact on criminal cases because the vast majority of assaults are by males upon females.

A hand shot up in apparent response to this last point. It belonged to Ms. $S$, the woman who had resisted the assignment to defend the marital exemption on the previous day. The look in her eyes of determination (or was it hostility?) surprised me. The comment that had triggered her response could well have been uttered by a feminist committed to safeguarding women. ${ }^{29} \mathrm{I}$ continued with my concluding comments, all the while wondering whether I should suspend my declaration that discussion was over. If I recognized Ms. S, I would risk the resentment of other students who had wanted to talk earlier, but if I ignored her obviously powerful desire to speak her mind, I would risk her ire in or out of the classroom. I opted to call on Ms. S.

Ms. $S$ began by restating my observation about the predominance of male assaults on females in a way that obviously distorted my words. When I interrupted to point that out, she conceded as much, but then forged ahead, declaring that she took issue with the implication that protecting men against sexual assaults by other men was unimportant. Because I was somewhat at a loss, I asked the class whether I had said what Ms. S was asserting. They resoundingly disagreed with her construction of my words. I then reiterated my points: that statistically the vast majority of sexual assaults were committed by men upon women and that gender neutrality would not have a substantial practical impact. Ms. S pressed further, again alleging that I had demonstrated a lack of concern for victims of homosexual assault. In a plea for understanding, I stressed that I did not believe the criminal law should exclude male victims

\footnotetext{
tension between the special character of the offense and the need for fair treatment of all criminally accused individuals. I have always resisted the call to change the rules when trying accused rapists and continue to question the propriety of doing so. The danger inherent in every pendulum is that it will swing from one extreme to the other without pausing in the middle. My increased knowledge, however, has made me more sympathetic to the view that rape has special aspects that should make one look all the more closely at the effects of particular procedural rules and safeguards.

28. The two other arguably unique aspects of rape that $I$ alluded to were: (1) that the conduct that is criminalized by rape laws is, absent force or some other unacceptable "imposition," frequently engaged in and desirable activity; and (2) that social stereotypes have had and continue to have a profound influence upon the law. Neither of these reflections triggered a response.

29. I was not surprised, but was quite amused, to learn a few weeks later that Professor Catharine MacKinnon had made the very same point in her mini-course, Sex Equality, at Michigan during the preceding fall semester. She had apparently gone further, suggesting that because women are the usual victims of rape statutes should not be gender neutral. I realize that on this issue, like many others, feminists can be found on both sides. See Nancy S. Erickson \& Mary Ann Lamanna, Sex-Bias Topics in the Criminal Law Course: A Survey of Criminal Law Professors, 24 U. MiCH. J. L. REF. 189, 210 n.55 (1990) (observing that "not all feminists see the adoption of sex-neutral terminology for victim and offender as a desirable reform"). I had assumed, and still assume, that few would disagree with the assertion that sexual assault victims are predominantly female.
} 
from its protective sphere and had not intended to imply anything remotely like that. With perfect timing, an anonymous male voice added, "Nor did you!"30

I had almost made it through the week unscathed and then, just as the curtain was coming down, lightning had struck. Granted, it could have been much worse. If the students had not made it clear-with sighs and moans-that they completely disagreed with Ms. S and were in outright sympathy with their poor misunderstood professor, the episode would have been much more unpleasant and perilous. Nonetheless, it was an intense, one-on-one emotional struggle of the sort no instructor desires in front of an entire class. Moreover, the lightning had come out of a cloudless sky. I had a sound educational purpose for concluding with comments about what I had learned and thought that I had formulated them so as not to offend anyone. ${ }^{31}$

\section{The Aftermath - Feedback and Invisible Undercurrents}

When class ended Ms. S was the first to arrive at the podium. She reiterated her point at length, related that she had more than one male acquaintance who had been sexually assaulted, and suggested that perhaps the reason that male assaults on males were statistically small in number was that men were deterred from reporting by the humiliating and demoralizing nature of such an attack. ${ }^{32}$ After I invited her to furnish any studies that might demonstrate the error of my statistical observation, Ms. S changed the subject. She apologized for her performance-rather, her refusal to perform — when asked on the preceding day for a modern defense of the spousal exemption. She asserted that she just could not defend a position with which she so strongly disagreed. I resisted the temptation to lecture her about how good lawyers develop the ability to understand and make the arguments of their opponents, and shortly afterwards Ms. S departed.

Two other students were waiting at the podium. Ms. P, a frequent contributor to the classroom discussion who was one of the students frustrated when I had declared our discussion of rape shield laws at an end, began by telling me that

30. At some point in the exchange, I added-in total frustration at what seemed like a resolute determination to misconstrue my message-that it would be foolish for me to advocate what she had heard because "after all, I'm a man!" As soon as these words escaped my lips, I sensed that I might have crossed the line of propriety. I was not sure what offense might have been given, but by this point I had limited faith in my ability to perceive the potential for offense. I wondered whether the fact that I was smiling at the time, coupled with the fact that a considerable number of class members found the remark amusing, might lead some to believe that I was being inappropriately flippant. I received no reports of negative reactions, perhaps because the students were so clearly on my side at the time. Had they not been, my remark could have turned out to be a costly slip of the tongue triggered by an unforeseeable classroom exigency.

31. The lesson I learned was that you can never be sure of making yourself understood in this area of law. For me, one of the ironies of this situation was that in my concluding comments I had told the students that the study of rape law had once again brought home to me the importance of keeping an open mind on every question.

32. Statistics indicate that sexual assaults upon women are grossly underreported-more so than perhaps any other crime. See ESTRICH, supra note 11, at 10-11. 
she just had to express some things that were on her mind. First, she was worried that the reason I had refused to call on her that day was that I had assumed that I knew the position she would take and did not want to hear it. I was flabbergasted and told her that she was very wrong in her assessment. She had in no way been singled out. We professors must constantly make decisions to call or not to call on students and to extend or end debate. Moreover, I valued her input in general and had not even considered what her views might be. Nonetheless, she added that I would have been surprised to learn that she did not think it appropriate to allow accused men's past instances of aggression into evidence.

She then turned to her more compelling concern. With evident emotion, Ms. $P$ informed me that there were women in the class who had been sexually assaulted. She felt that the discussion of rape had at times been insensitive to these women. I was astounded, saddened, and deflated. I responded that I had gone out of my way to prevent such injuries and asked her for specifics. The only concrete thing Ms. P pointed to was the fact that I had opened the topic by reading from newspaper accounts of recent rape cases. Her impression was that I had done so with a lighthearted, somewhat cavalier attitude. I assured her that had not been my intent, and that my objectives had been to establish the social milieu in which rape law operated and to illustrate the prevalence of rape. She alluded to the fact that my teaching style incorporated healthy doses of humor. I admitted that was my technique, telling her that it had proven to be an effective and often necessary way of keeping a class alert and involved. ${ }^{33}$ I then asked whether I had in any way joked about sexual assault during our discussions. She assured me that I had not.

Ms. P said she did not mean to suggest that the week had been an awful experience - just that matters could have been handled better. I expressed sadness to learn that any anguish had been caused by the classes and voiced a concern that discussions of rape might inevitably, albeit inadvertently, inflict emotional distress upon rape victims. After we spent perhaps forty minutes traversing the same ground from a variety of directions, it appeared that Ms. $P$ believed in my goodwill, was neither angry nor agitated, and was relieved that she had found the courage to express her concerns.

After Ms. P left, I turned to another student who had waited patiently for nearly an hour, bracing my psyche for what would surely be another negative report. This student, Ms. T, began by telling me, in the kindest of tones, that I had done a remarkable job of maintaining balance in the classroom and of treating the topic of sexual assault fairly. I breathed what must have been an

33. It is always a challenge to keep the majority of a large law school class engaged for an hour. In an ideal world, every faculty member would be hypnotically interesting and every student would be devotedly attentive. In the real world, however, the faces of students frequently evince weariness, boredom, or distractedness. I have found that humor is among the most effective ways to keep the maximum number of students focused on the classroom dynamic. 
audible sigh of relief and thanked her abundantly. She suggested that while teaching rape was, in some respects, a "no-win" situation for the professor, I had done as well as could be expected. When Ms. T implied that complaints that I was insensitive to women were probably unavoidable, ${ }^{34}$ I winced, expressing the hope that she had not actually heard any pejorative epithets directed toward me. She quickly assured me on that score, but added that after one class she had heard a woman say that she "couldn't believe Tomkovicz could say such a thing." I did not ask for specifics. I realized that despite my announcement that I would not be offering my own views on the issues at hand, a student had "heard" me endorse an "incorrect" (by modern, right-thinking standards) position. Finally, Ms. T reported that she had brought to the topic predetermined views that favored protecting women. She said that she had learned a lot about the difficulty of formulating precise lines that criminalize only those one wishes to punish, and that she was now less likely to blindly criticize legislative failures. I was pleased at her enlightenment, once again thanked her for her thoughtfulness, and we parted company.

I finally reached the faculty lounge, where I related the in-class confrontation with Ms. S to a handful of listeners. ${ }^{35}$ All were amused at the nature of the challenge and the obvious miscommunication. Before my next class that afternoon, I shared the day's events and my thoughts about them with both a clinical professor and my research assistant, a third-year student. Both women understood why I might be troubled by the events and why they might make me think twice about teaching rape in the future. Yet both counseled me not to be deterred from addressing this important subject in future semesters at lowa. ${ }^{36}$

By the time I arrived at my afternoon class, I was fatigued. I survived the hour, then returned to my office, where another student from my criminal law course, Ms. V, was waiting. Much to my relief, she had no complaints. She wanted to share the story of a recent rape case in her home town, and she had some distinct views on the Tyson trial-which had ended the previous evening in a guilty verdict. Ms. $V$ proceeded to share her observations about some male classmates, saying that it was amazing to witness how the attitudes they expressed varied in different settings. In a group they tended to complain about the "politically correct" tenor of our classroom discussion of sexual assault.

34. I am almost certain that Ms. T used some unappealing label such as "sexist" to illustrate her point. Whatever the precise language, the implication was that some students had categorized me as a result of the class discussions.

35. Students may think that they alone discuss the noteworthy events that occur in class, that faculty hardly take note of them and certainly do not share them with colleagues. That is not the case. We faculty need to vent, to purge ourselves, to share war stories for all the reasons that other human beings do. I should note that out of sensitivity to Ms. S's interests I did preserve her anonymity.

36. I have never been similarly urged by a male criminal law teacher. I cannot help but think that the women who have exhorted me to teach rape might be a little less avid in doing so if they could trade places with me and experience the risks first hand. I suppose this is similar to the wish that many women have when trying to convey to men the realities of their suffering in certain situations. 
When they spoke individually to her, however, they had no need for macho bravado, and were quite willing to venture views that were sensitive to women's concerns. I was pleased to hear of the latter, but a bit dismayed that there could be any sense that I had allowed a dominant, "correct" viewpoint to prevail—or, worse yet, that I might somehow have espoused that viewpoint. Did I feel caught in a crossfire? Damned if I did and damned if I didn't? The victim of a no-win situation? Without a doubt!

During the remainder of the week, I related some of my experiences to senior faculty members, particularly those who had taught criminal law. One agreed that teaching rape was a minefield. Another seemed amused, for he had managed, year-in and year-out, to traverse the terrain without incident. I was told that explosive reactions to the teaching of rape were not atypical in the Michigan Law School, that one faculty member always had "trouble," that another was known to have had resentful women walk out of his classes, and that one former faculty member had attempted to teach the subject for a few years before giving up the effort as not worth the costs. Thankfully I did not learn from any more students in my course that they were hurt, unhappy, or displeased with the week's study of sexual assault. To the extent that I heard anything, it was that the week had been a valuable educational experience.

Then I learned quite by happenstance of one more relevant event. After I had commended one of the women in the class, Ms. O, for her contributions to a particular homicide discussion, she ventured the observation that she sometimes spoke too much in class. I told her that in my opinion that was not at all the case, whereupon she somewhat emotionally confided that she had been deterred from speaking in my class by a painful experience earlier in the semester. She had expressed a view for which she had later taken intense heat-particularly from a good friend who "couldn't fathom" how she could say what she had said. My immediate response was that no one should have attacked her, and that she should not be discouraged from speaking. I invited her to stop by my office to discuss the matter further.

I immediately recalled the in-class comment that had gotten this thoughtful student into trouble. A couple of weeks earlier, we had been discussing "mistake of fact" and the mens rea that should be necessary for rape. ${ }^{37}$ She had volun-

37. The discussion of the appropriate culpability requirement for an accused rapist regarding the element of the victim's "lack of consent" focuses, in large part, upon the infamous House of Lords opinion in Regina v. Morgan, 1976 App. Cas. 182 (appeal taken from C.A.). In that case, a protesting woman was sexually assaulted by three men who had been drinking with her husband. The assailants claimed that the victim's husband had told them that they could have sex with her and that, even though she would protest, she would be enjoying it. When tried for rape, the men asserted that their belief that the victim consented was a defense even if the belief was unreasonable. The Law Lords caused quite a stir in England-and continue to cause similar stirs in American law schools-by opining that rape, a serious offense, requires an actual awareness that a woman is not consenting to intercourse, and, therefore, that a defendant's mistaken belief need not be reasonable. While affirming the convictions on the ground that properly instructed jurors would still have convicted the men, Lord Hailsham wrote that since "rape is non-consensual sexual intercourse, and ... the guilty state of mind is an intention to commit it" an "honest belief" that a woman is consenting precludes 
teered the view that there is a difference between a stranger who grabs a woman and violently forces intercourse upon her and an acquaintance who persists in the face of refusal. ${ }^{38}$ Another woman had forcefully repudiated that distinction, plausibly arguing that both were rape and asserting that acquaintance rape could be worse for a victim than stranger rape. I had realized at the time that the position that there is a clear distinction between stranger and acquaintance rape is extremely unpopular in certain circles. I had not realized that Ms. O had been censured and censored for her "heresy." Upon reflection, it occurred to me that Ms. O's welcome, regular contributions to the classroom dynamic had all but disappeared, and that she had said little, if anything, during the week on rape. Now I knew why, and I was more than a little disconcerted.

A couple of weeks later, I met with Ms. $O$ in my office. She told me that when she had expressed the opinion that stranger and acquaintance rape were different she had felt as if the entire class was against her. Her friend's post-class castigation had been devastating, and had made Ms. O question whether she belonged in law school. Fortunately, some classmates had supported her, and she had weathered the storm.

I had several strong reactions. I was angry that free thought was being suppressed in the halls of the Michigan Law School. I was determined to ensure that Ms. O felt supported and at home in my class. I was grateful to the classmates who had shown compassion. I was sorry that this bright, decent student had again been victimized and hurt by narrow minds. ${ }^{39}$ I was upset that her expression of an honest, reasonable opinion had resulted in emotional suffering. I forcefully advised Ms. O not to be intimidated by those who were intolerant of diverse views. I let her know that she was a valuable contributor to the life of the law school, and that she had best prepare herself so that she

conviction because it "clearly negatives intent." Id. at 214.

While I understand the hostile reactions to the Morgan opinion, I have never thought that its reasoning or holding is beyond the pale. The assertion that the most serious forms of sexual assault-those that yield the stigma of "rapist"-should require proof of "subjective culpability" is plainly defensible. (Not correct, defensible!) Students, however, do not usually find the Morgan holding to be an attractive resolution of the mens rea question. Because they refrain from defending it, I frequently must present the arguments that support it.

38. I have encountered the contrary view-that rapes are all of one kind. That position seems inconsistent with the criminal law's inclination to grade offenses within a given category according to severity. Not all unlawful killers are treated alike, even though the harm they have done is identical. The preferable approach would seem to be to endeavor to grade sexual assaults according to the degree of harm done, the culpability of the offender, and other relevant criteria.

I should add that Ms. O did not say, nor would I assert, that compelled intercourse that does not involve a stranger, multiple assailants, a weapon, or physical brutality is not "real" rape. Professor Estrich has convincingly argued that "[s]imple rape is real rape" and requires condemnation. ESTRICH, supra note 11, at 104.

39. Before my meeting with Ms. $O$, I had learned of a relevant incident from the fall semester. It seems that Ms. O had mustered the courage to offer the opinion that Roe v. Wade, 410 U.S. 113 (1973), had been wrongly decided. Her "anti-abortion" position had apparently brought derisive laughter from several members of the class. 
could respond with pointed self-assurance to the next attempt to compel intellectual conformity. She seemed bolstered.

\section{PRESENT}

I imagine that the events I have recounted have disappointed more than a few. Those who expected, or desired, evidence that it is impossible to teach rape without catastrophe will have to look elsewhere. Those who hoped to savor a tale of passion and conflict as the radically politically correct and the embattled male traditionalists had it out in the classroom while a foolishly optimistic law professor tried to referee must feel cheated. The preceding events contain but a few morsels for the devotee of modern American absurdist drama. Moreover, mine is not a horror story designed to prove that rape is too controversial and that interest groups will make even the most well-intentioned (male) teacher's life a living hell. Those who feared such a story must be relieved at the dearth of fireworks. Still, they cannot be entirely content with my mini-saga, for there was more than enough unpleasantness to give one pause-especially one given to wonder about the potential icebergs below the surface.

\section{A. Lessons Learned-Reasons and Risks}

Having related these episodes, I feel obliged to reflect upon them and to explain the particular lessons I have learned. I am well aware that others might hear quite different voices from the same experiences.

\section{Valid Reasons for and Invalid Reasons Against Teaching Rape}

When confronted with the prospect of teaching rape in past years, I took refuge in two assertions: (1) The omission of rape is inconsequential, for its study would not contribute anything important to the criminal law course that I teach - one devoted to general theoretical principles; and (2) There is simply no room in the present schedule; to accommodate rape I would have to displace a more important subject. I hope that honesty will prevent me from relying upon these familiar defenses in the future. I now believe that the first is erroneous and the second is either of questionable validity or minimal weight.

\section{a. The Important Legal Lessons of Rape Law}

Our discussion of sexual assault taught me and the students several important general lessons about the criminal law. ${ }^{40}$ We learned about the difficult balance

40. See Erickson \& Taub, supra note 5, at 314-15 (asserting that "the inclusion of topics of particular concern to women will enrich traditional courses," and "may be used to illuminate some fundamental doctrines 
the criminal law endeavors to strike between societal protection and unjust criminalization of the innocent or insufficiently culpable. For example, women are arguably better protected when rape law ignores an accused rapist's belief about his alleged victim's willingness to have intercourse. That approach precludes the possibility of an exculpatory lie and encourages more care by men in assessing ambiguous situations. The price of such protection, however, could be a stigma and sentence disproportionate to a particular offender's moral fault.

We experienced first hand the difficulty of drawing the line between criminal and noncriminal acts in the area of sexual assault. Every change in perspective-from emphasis on victim protection, to adherence to constitutional safeguards, to focus upon the need for a guilty mind, to recognition that many men deal with women from positions of power that are prone to abuse-highlighted a different flaw or virtue in the variety of possible boundaries between criminal assault and noncriminal imposition. For example, the focus on force, narrowly defined, seemed to exclude some coercive overreaching by men that is injurious and blameworthy. On the other hand, a definition that prohibited any coercion or pressure to engage in intercourse seemed to encompass behaviors that, while not socially commendable, are not fit subjects for criminalization-at least not as rape. Moreover, that perspective engendered difficult problems of definition and degree. Finally, a mere lack of consent standard seemed to invite too much focus on the victim and too little focus on the wrongful conduct of the accused.

We perceived the bias that a male-oriented perspective has incorporated into past and present law. The need for "utmost" or "reasonable" resistance, the restrictive focus on physical force alone, the demand for a "reasonable" fear of serious harm, and the corroboration requirement all evidenced this bias. We also saw how social change and the abandonment of stereotypes can have dramatic impact upon the shape of the law in a relatively short time. The abandonment of the utmost resistance requirement, the broadening of the definition of force, the introduction of gender-neutral terminology in some modern reform statutes, the dramatic erosion of the spousal exemption, the disappearance of the corroboration requirement, and the widespread adoption of rape shield statutes illustrate this phenomenon.

I was educated by reading the views of thoughtful, concerned women, and by hearing the strongly felt positions of well-educated young adults. I questioned my own preconceptions, and was reminded of the need to doubt every

in criminal law"); id. at 352 (explaining that rape law "involves many of the central doctrines of criminal law"); Erickson, Sex Bias, supra note 5, at 105 (maintaining that "[a] gender-related topic . . . may serve [pedagogical] goals as well as or better than topics that have been traditionally used"). 
conclusion-and I trust that some students had the same experience. ${ }^{41}$ All of these valuable legal lessons-and more-make the study of rape in a basic criminal law course worthwhile. And, I should add, they have made me want to continue to study and teach the topic.

\section{b. The Social Significance of Rape Law}

A certain number of students undeniably and justifiably feel deprived when rape law is omitted from the curriculum. ${ }^{42}$ Law schools arguably have an obligation to provide opportunities for the lawyers of tomorrow to examine controversial social issues like rape, and to learn from the analysis of competing reasons, arguments, and viewpoints. Sexual assault is a vital, central concern for both women and men, and the law's response is of critical importance. All women are potential victims. All men are potential defendants. And both women and men can be the parents, sisters, brothers, and friends of victims and defendants. All of us ought to be interested in a criminal law that protects victims and treats accused individuals fairly. There are good reasons to expose all those who might shape the future contours of that law-as judges, legislators, appointed officials, and public or private attorneys - to the variety of questions and concerns that make rape so difficult a social and legal topic. ${ }^{43}$ The likelihood that individuals will approach this subject with rigid, unanalyzed preconceptions makes the need to explore mind-opening possibilities all the more important.

I do not mean to suggest that the study of rape in first-year criminal law-or anywhere in law school-is indispensable. I may be a convert to the view that it is important, but I am not a zealot prepared to preach that it is essential. To those who might wonder how I could possibly exclude rape from the catalogue of indispensable law school topics, my simple answer is that I have no such catalogue. In my view, many legal topics are important, but none is indispensable. I feel no obligation to ensure student exposure to any particular topic.

\footnotetext{
41. I also trust that some students did not have the same experience. I continue to be to surprised at the number of bright, highly-educated minds that are tightly closed about certain subjects. I am not sure of the reasons for an unwillingness or inability to question or reexamine views or consider alternatives. I am sure that the resulting mindset is incompatible with some of the primary objectives of legal education.

42. See Erickson, Legal Education, supra note 5, at 459 (asserting that "sex bias in legal education" has "devastating" effects on women students); Erickson, Sex Bias, supra note 5, at 105 (maintaining that "women students may take superficial coverage [of topics with which they are concerned] as evidence that their experiences and concerns are devalued in legal education"). I agree that the climate of law school should not be unnecessarily inhospitable to any group or individual, and it is certainly conceivable that the omission of rape law from the criminal law course could create a perception that women's concerns are not taken seriously. That perception would militate in favor of including rape in the course. I have not discussed this topic at length in the text because I have tried to confine this Essay to lessons learned from my own experiences. Those experiences have not provided evidence that excluding rape has such an alienating effect.

43. See Erickson \& Taub, supra note 5, at 313 (arguing that the fact that "law schools train a very high proportion of ... policymakers" makes it "vital that the curriculum reflect issues of concern to more than half the population").
} 
I would concede, of course, that it would be difficult to study criminal law without an understanding of foundational principles such as the actus reus and mens rea requirements. But one could become a very good lawyer without studying criminal law at all..$^{44}$ My point is that the study of rape is important but is not a sine qua non for the well-educated lawyer.

\section{c. Room in the Schedule for the Study of Rape}

The second reason to which I have clung - that the inclusion of rape would require displacement of a more important subject-is not without force. Every topic in my introductory criminal law course makes a significant contribution to a general understanding of the nature, purposes, objects, underlying principles, and past and present structure of our criminal law. The insights gained from teaching rape, however, have led me to conclude that rape law's contributions are no less significant than the contributions of several other subjects. ${ }^{45}$ Only past practice and habit justify the choice to teach those subjects instead of rape. Moreover, if social importance were to serve as a tiebreaker, rape would merit priority over many of those subjects.

In addition, just three hours are needed to cover the essentials of rape law. A will to include rape coupled with a little ingenuity-perhaps compressing the coverage of other subjects or adding supplementary class hours-would undoubtedly yield a satisfactory solution.

\section{d. The Inadequacy of Resentment and Suspicion}

I mentioned earlier that another implicit reason for not including sexual assault in my course has been a sort of resentment bred by the attempts of others to dictate the content of my course. I admit to an all-too-human suspicion about the motives of those who would infringe upon my academic and professional freedom. ${ }^{46}$ I hardly need add that these emotional reactions are not sound

44. I apologize to my criminal law colleagues for the apostasy. Perhaps I can make amends by acknowledging that criminal law's prominent place in the lives of all members of society-and its central role in the rhetoric and election strategies of our politicians-makes it one of the most important basic subjects taught in law schools.

45. Teaching rape in a mandatory criminal law course is not the only option. One of my Iowa colleagues designed a course called Women and the Criminal Law and taught it for the first time in the fall of 1991. Rape was among her central concerns. A Michigan faculty member told me that she might like to teach an interdisciplinary law school seminar on rape-a course that would incorporate legal, sociological, philosophical, ethical, and other perspectives. Both of these courses seem like good ideas that would minimize some of the risks enumerated below. Nonetheless, the reasons that rape law is an important subject all militate in favor of exposing the entire entering class to the topic. Specialized courses tend to attract individuals interested in the particular subject matter, often those with certain predispositions. See Erickson and Lamanna, supra note 29, at 192 (confining the treatment of "gender-related topics" to specialized courses means that "the majority of students . ... may have little exposure" to them).

46. It is not my intent to suggest here that legitimate resistance to efforts to constrain such freedoms is unwise or unjustified. 
reasons to exclude a topic that otherwise deserves a place in the curriculum. Neither do inertia, laziness, or the comfort of well-known territory justify a refusal to assume the responsibility of teaching rape.

In sum, my past justifications do not support the continued omission of sexual assault from my course. Moreover, there are good reasons to include the topic. The question that remains is whether there are reasons that might justify its omission.

\section{Legitimate Justifications for Not Teaching Rape}

My experiences at Michigan have persuaded me that there are several substantial bases for a decision not to teach rape in first-year criminal law. These lead me to conclude that one can make a responsible choice either to teach or not to teach the topic. Some may accuse me of providing transparent rationalizations for preserving the status quo. They may suspect that the justifications provided have been contrived to furnish shelter for the profoundly timid or irresponsible. I can only answer that I have engaged in this enterprise with an open mind and the best of faith. I struggle against my own unwarranted suspicions about others' motives and agendas and hope that readers will do the same in judging my thoughts.

\section{a. The Educational Risks of Teaching Rape}

Discussing rape has the potential to destroy or at least severely damage the educational atmosphere in the classroom. First, clashes between students that cross the borders of legitimate, respectful, professional discourse can lead to tension, hard feelings, and censorship. I was fortunate that no such encounters marred my academic endeavor. ${ }^{47}$ Perhaps this was due in part to the fact that I introduced the topic by expressing a desire for sensitive and respectful discussion, but I am more inclined to believe that I was just lucky. From the experience of others who have taught rape and other controversial subjects, I know that emotionally-charged debates can degenerate into personal insult and invective. ${ }^{48}$ Such exchanges are educationally counterproductive in both the short and long runs.

47. There were none in the classroom that I could perceive, but there was one quite significant encounter outside the classroom that threatened the education of and silenced one student. See supra text accompanying notes 38-39.

48. I do not believe that any event fitting that description has ever occurred in one of my classrooms. While at Michigan, however, I learned of two such episodes that had occurred in my section's first semester constitutional law course. In one, a student exchange over affirmative action prompted the pro-affirmative action student to suggest that his opponent lacked intellectual credentials because he was a transfer student from a much less prestigious law school. The other occurred when Ms. O voiced an unpopular view on abortion. The inconsiderate laughter of her classmates inflicted emotional pain. See supra note 39. I am sure others could add similar incidents. 
Second, personal conflicts between students and the instructor might generate antipathy and mistrust that can spread throughout a class-or a segment sizable enough to damage the classroom dynamic. ${ }^{49}$ There was a palpable potential for lasting harm when Ms. $S$ confronted me over a perceived lack of concern for sexually assaulted men. If her misunderstanding (or unwillingness to understand) had not been so patent to the rest of the students, or if I had not been able to find a tactful way of responding, ${ }^{50}$ a significant number of students could have been alienated..$^{51}$ Moreover, it is entirely possible that students will disagree violently with what they perceive to be a professor's views but will not openly express their feelings. In such cases, hostility and suspicion can poison student-teacher relationships and dampen desires to participate in the classroom.

I do not believe that an instructor can eliminate such risks by openly stating his or her views. A consistently pro-victim, feminist orientation will undoubtedly alienate a certain segment of the population that prefers more traditional positions. And more conventional views rooted in concern for the accused will offend the segment that believes that the law fails to protect female victims. Espousal of mixed views that include some from each camp will, of course, manage to irritate both extremes.

I can hear some saying that the solution is simple: to profess no views on any of the issues, but merely to teach the law. My answer, rooted in experience, is equally simple: some with deeply held convictions will hear what they want to hear or will assume that any professor who is unwilling to endorse their side of the debate must be on the other side. ${ }^{52}$ I explicitly told my class early in the semester that they would not know my views, and that my job entailed proffering possible arguments whether or not I supported them. ${ }^{53}$ Despite that,

49. I am not suggesting that the Iaw school classroom should be conflict free. On the contrary, I am always eager to encourage lively intellectual exchanges between students and willing to engage in pointed academic debate. The conflicts and clashes that I find detrimental are of a wholly different order. They are personal and excessively emotional. They provoke resentment, hostility, and suspicion. They have a serious potential to embarrass and humiliate. They threaten psychic pain, but promise no offsetting benefits. They are unnecessary to and destructive of the educational process.

50. Several students told me that I had handled the situation well. Ms. S later informed me, however, that immediately after the incident several students had agreed with her assessment that I had "humiliated" her.

51. Since my earliest days in teaching I have been aware of the inherent solidarity of a class of students and of the fact that a professor who wrongs, or is perceived as having wronged, a student in class risks the wrath of a united front. The risk of such a response is all the more acute in a first-year section that possesses a group identity and a degree of insecurity that heighten its solidarity. When I am forced to respond to an agitated or hostile student I try to bear these facts in mind and to remain sensitive to the temper of the whole class. If I can avoid alienating the entire class, or any large segment of it, I prefer to do so.

52. This "if you're not with us, you're against us" syndrome has two equally virulent strains. The first holds that anyone who does not adhere to a preferred view is an opponent by virtue of the refusal to lend support. The second presumes that unwillingness to endorse a preferred view is proof of adherence to the contrary position.

53. I strongly believe that a professor of law should neither "preach the gospel" nor endorse one side of a debate as hers, his, or the "right" one. (I do, however, recognize and respect my colleagues' differing opinions about the propriety of doing so.) I have two reasons for adopting this view. First, I believe that it is an abuse of the power of the podium. We who teach learn fairly early on in our careers-sometimes 
some students apparently found me guilty of endorsing unacceptable views or of allowing currently "correct" views to take control. For some-probably those who entered with strong feelings one way or the other-I could not have distanced myself from either the arguments I voiced or the positions that they inferred from my ambiguity or silence. To the extent that their disagreement with positions they attributed to me bred resentment and distrust, the classroom was undoubtedly affected.

My intent is not to suggest that my criminal law course at Michigan went downhill after the rape chapter, having suffered an injury from which it could never quite recover. In fact, the classroom dynamic remained positive and productive. My point is that despite all my care and concern with avoiding harm to the climate, there were indications that some damage was done and that other threats were present. A classroom discussion of rape creates nonnegligible risks that the entire educational enterprise will be seriously impaired. ${ }^{54}$ It is possible to limit and lessen the perils, but they cannot be eliminated. I have had few colleagues who are unconcerned by serious damage to the learning environment. I know of many who care too much about educating all their students to ignore risks such as those I have described.

\section{b. The Professional Risks of Teaching Rape}

Teaching rape also involves potential harms to an instructor's professional status that are intertwined with the educational risks. Law students come to classes with certain preconceptions about faculty passed down by generations of predecessors. They "know" in advance that we are "good" or "bad" or "boring" or "brilliant" or "inept." They also "know" if we are "racist" or "sexist" or "conservative" or "liberal" or "radical" or "self-absorbed." Our professional reputations bias classes in favor of or against us, influence students to select or not to select our courses, and if they enroll, to see us in predetermined ways. Some of us enjoy excellent reputations in most if not all respects and seek to preserve them. Others who suffer negative reports sometimes try to change them or sometimes resign themselves to swimming upstream. Professional reputations

to our surprise-that we wield an enormous amount of power from the front of the room. We can boost or humiliate, embarrass with criticism or elevate with praise, and, I think, profoundly shape young minds. I do not mean to suggest that all of the impressive intellects I have encountered at Iowa, UCLA, or Michigan are malleable-many are disturbingly inflexible. Nonetheless many, perhaps a "silent majority," remain impressionable. Out of respect for them, and because I have enough self-doubt to wonder how much of the truth I possess, I refrain as much as I can from endorsing particular positions. Second, I believe that a professor who promulgates "preferred" viewpoints risks the alienation of one group, several groups, or all groups. Alienation can damage the intellectual environment in a variety of ways. I want to maintain an atmosphere that welcomes all viewpoints because I believe that such an environment is most intellectually stimulating and educationally beneficial.

54. If I could be guaranteed in advance that the risks and consequences would be as limited as they were at Michigan, I would not hesitate to teach rape. No such guarantee is possible, however. 
have integral roles in our careers. They affect our daily institutional lives and have profound impacts upon our classrooms.

In addition, most law schools are relatively small communities in which news travels quickly and pervasively. In these fishbowls, one event can easily injure a reputation. Students avidly share noteworthy classroom occurrences, revelations, pronouncements, and slips of the tongue. Like most human beings, they show a special interest in the unpleasant or negative. A professor who missteps in teaching rape-through bad judgment, poor communication, misunderstanding by students, playing the devil's advocate a bit too fervently, or stressing a belief in the primary importance of Bill of Rights protections for criminal defendants, including accused rapists-might be branded an archaic, insensitive sexist who cares little for women and favors the sexual prerogatives of men. ${ }^{55}$ Whether deserved or undeserved, such reputations sometimes gain sufficient steam to take on lives of their own. Moreover, once such ill-repute takes root, it is difficult, if not impossible, to eradicate. Successive generations of law students learn of the conclusion long after its origin fades from memory.

In sum, teaching rape engenders an undeniable risk that students will form an ill-founded, unfavorable, even downright damning impression of the instructor. ${ }^{56}$ Such an impression can pervade the community and become an enduring reputation that is, to say the least, professionally undesirable and educationally counterproductive.

Turmoil spawned by classroom discussions might consume inordinate amounts of time outside the classroom. Students can go to administrators, who may summon the faculty member. ${ }^{57}$ They can contact the media, who may seek to interview the instructor. Students may simply pursue the instructor, engaging in lengthy conversations about his or her unacceptable views, or seeking retractions, confessions, or apologies. At Michigan, I spent too many hours meeting with students, talking to administrators, and dwelling upon the relatively minor episodes that had upset me. I am perfectly willing to devote the time needed to address student perceptions, concerns, and misunderstandings, but there comes a point when the time spent outweighs the conceivable gains. If the few, mild events that I witnessed could be so frustratingly wasteful of

55. Something like this once happened to me. Almost ten years ago at Iowa, I leamed that a young woman in my criminal law course was telling other students that I was "pro-rape." The basis for her conclusion was my discussion of the disfavored House of Lords opinion in the Morgan case. See supra note 37. Apparently, the student understood my explanation of the argument that a negligent man should not be branded a rapist as a declaration that I was in favor of the rape of women. The parallels to the in-class episode at Michigan concerning my alleged assertion that men should not be protected by the criminal law against homosexual assault are unmistakable.

56. See Erickson \& Taub, supra note 5, at 313 (observing that women students have expressed considerable concern about how sexual assault cases are taught); $i d$. at 340 (noting that professors have reported criticism by female students for their approaches to teaching rape law).

57. One of the few times I have ever been so summoned because of student discontent occurred at Michigan, when an administrator called to inform me of a student's discomfort spawned by one of the events that I have described. 
professional time, what would have been the price of a major episode or confrontation? I can only hope never to find out.

\section{c. The Personal Risks of Teaching Rape}

Both students and professors can suffer personal harms due to classroom discussions of sexual assault. There are women in law school classes, and perhaps also men, who have been victimized by rape. ${ }^{58} \mathrm{I}$ do not know how it feels to discuss the subject, or sit through such a discussion, after having suffered that trauma. While reactions no doubt vary, I can only surmise that for many it is painful to be forced to dwell upon the topic, to read and to hear about it. It is possible that some students derive little educational benefit from a discussion of sexual assault, either because they are too traumatized to think clearly about the issues, or because they choose to avoid class during the time devoted to rape. My point is that one should not ignore the possibility that the classroom dialogue about sexual assault causes personal anguish to a certain number of victims of the crime. ${ }^{59}$

Furthermore, a student might suffer for his or her opinions, chastised as Ms. $O$ was for voicing the moderate view that there are degrees of rape. ${ }^{60}$ Students with unpopular views must either swallow them and live with the discomfort of censorship, ${ }^{61}$ or voice them and risk wrath and obloquy. Such alternatives are hardly appealing.

The risks for faculty have a personal dimension as well. Personal and professional lives are not completely separable, and faculty are not immune to mental suffering. Harm to one's reputation in the law school community entails personal pain for all but the jaded, and few relish an unfair pejorative label or the promise of ill-will from future students who learn nothing but simplistic summaries of often complicated events. Moreover, it is distressing to learn that students have been alienated, offended, or ostracized as a result of classroom discussions. At Michigan, good days turned bad when I was misunderstood, classified, or suspected.

58. See Erickson \& Taub, supra note 5, at 340 ("Some women law students already have been victims of rape, and many of those who have not been victimized may feel particularly vulnerable to this crime.").

59. In most classes there are probably students who have been the victims of a variety of other crimes. The victims of most other crimes, however, probably do not suffer the intensity of personal injury suffered by rape victims. Moreover, the injury from rape seems likely to last longer.

60. I am well aware that law school can be an inherently painful experience. Students, particularly during the first-year period of adjustment, suffer all sorts of blows to the psyche. The kinds of personal, emotional sufferings with which I am concerned here are excessive, atypical, and unnecessary. They do not belong in academia.

61. Some might call it self-censorship, but the reality is that the oppression of popular opinion is the silencing force. It takes considerable courage (or foolishness) to speak in the face of such pressure. It does not surprise me when students are unwilling to do so. I too have chosen silence. 


\section{Is Rape Special?}

If law teaching in general entailed equivalent educational, professional, and personal risks, it would be senseless and unfair to single out rape for possible exclusion from the curriculum. The fact is, however, that rape is one of a small set of hot button topics that trigger extreme reactions and counterreactions. It is the only topic in all the courses I teach-Criminal Law, Criminal Procedure, Advanced Criminal Procedure, Law and Psychiatry-that falls into that narrow category. ${ }^{62}$ Those with whom I have discussed the subject, including some who have taught rape in their criminal law courses, have similarly concluded that rape is an especially volatile topic. Discussion of the subject will evoke strong, sometimes irrational, often intemperate reactions.

I do not claim to know the reasons for this phenomenon. Perhaps it is that the vast majority of sexual assaults involve the victimization of women by men. ${ }^{63}$ Perhaps it is that rape remains a prevalent and critical problem in our society. ${ }^{64}$ Perhaps it is the perception that the predominantly male shapers of our law have moved all-too-reluctantly to eliminate harmful stereotypes of women and unfair advantages for men. ${ }^{65}$ Perhaps it is that many women, their relatives, and their friends have been injured, or that many men see themselves as potential targets of unfair criticism and unfounded serious charges. Perhaps it is a general unwillingness to be open-minded about controversial and emotional topics. More likely, it is some combination of all of these variables-and more-that guarantees a discussion of rape will be fraught with the potential for turmoil.

Whatever the reasons, men to whom I have spoken who have taught the subject in first-year criminal law courses generally agree that the risks are undeniable and unavoidable. ${ }^{66}$ Of the many legal topics I have taught to a large number of students during more than ten years, only rape has engendered the sorts of perils that surfaced during my visit to Michigan.

62. I teach a number of subjects that one might find controversial-homicide, coerced confessions, race discrimination in the selection of jurors, and execution of the mentally retarded, for example. In my experience none has engendered the emotions that rape, abortion, affirmative action, and hate speech can.

63. Ms. $S$ told me late in the semester that her research contradicted this assertion. The Department of Justice estimates, however, that in 19901.2 in 1,000 females were victimized by rape, while only 0.1 in 1,000 males were so victimized. The Justice Department noted that ten or fewer men in the 97,000 -person sample used as the basis for its estimates reported having been raped. BUREAU OF JUSTICE STATISTICS, U.S. DEP'T OF JUSTICE, SOURCEBOOK OF CRIMINAL JUSTICE STATISTICS 261, 725 (1990).

64. Just how prevalent is a matter of some dispute. See KADISH \& SCHULHOFER, supra note 1, at 365-66.

65. Features of some rape laws thought to provide male defendants with unfair advantages include, for example, the requirement of "reasonable" resistance, the marital rape exemption, the corroboration requirement, and lenient sentences for convicted rapists.

66. I assume that a woman might have fewer difficulties than a man-even if she played devil's advocate for disfavored arguments. But see Erickson \& Lamanna, supra note 29, at 238-41 (observing that women professors are "more likely to report polarization" of the classroom than men, probably because they "are more likely to experience" such polarization). 


\section{B. My Future: To Teach or Not to Teach}

At this point I am not certain that the law of rape will have a place in my future criminal law courses. My present inclination is to strike the balance in favor of teaching the subject, but I remain a bit ambivalent about the prospect. My risk-averse nature has kept me from making an unqualified commitment, and my propensity for excessive analysis has prompted continuous reflection and reconsideration.

Most women to whom I have described my past practice or expressed my current concerns have urged me unequivocally to teach the topic. ${ }^{67}$ Their tactful efforts to persuade me that there are solid reasons for including the subject and their heartfelt exhortations that it is the right thing to do have earned both my attention and respect. ${ }^{68}$ The thoughtful prodding of colleagues and students has counteracted the resistance I have instinctively felt to the mandates of others to mend my ways.

I was enlivened by the educational experience at Michigan and know that I have much more to learn. I gained insights into criminal law-insights, for example, into the difficulty of distinguishing criminal from merely immoral conduct and into the profound tension between changing social attitudes and entrenched traditions-that ten prior years had not taught. I was exposed to new thoughts, creative ideas, and different perspectives. I suspect that many students learned a good deal about criminal law in general and rape in particular. I was enriched, and I believe that students were enriched as well, by the valuable lessons in every class.

Many approach the topic of sexual assault with strongly held positions that have often been reinforced by a community of supportive associates, and that have never been challenged or questioned. As a result, a discussion of rape law holds somewhat unique educational potential. Those who enter with uneducated, unanalyzed preconceptions and conclusions-particularly those at either extreme-can have their minds opened to new possibilities. They can come to understand weaknesses in their views, and can be prompted to critically reexamine them. I am not suggesting that the opportunity for conversion to proper ways of thinking makes the teaching of rape particularly advantageous. I, for one, do not know that there are wrong positions that require correction. ${ }^{69}$

67. See supra text accompanying note 36 .

68. See Erickson, Legal Education, supra note 5, at 462 (projects concerned with "correcting sex bias in the law school curriculum ... deserve the respect and assistance of all thoughtful and concerned law professors").

69. I believe many things - some fervently. But there is a gulf between beliefs I have chosen to adhere to for good reasons and certain knowledge. In my experience, many devoted "believers" do not recognize or respect that gulf. As a result, they treat the beliefs of others as "wrong" or "ignorant" rather than "different." As the product of a religious tradition that used to treat others' beliefs in a similar way, I recognize the phenomenon. As someone who learned that belief need not entail righteousness, I have little tolerance for it. 
My point is that a robust, incisive, forceful debate concerning the legal treatment of sexual assault can begin to open closed minds and broaden narrow perspectives. Even if a preformed conclusion remains unchanged, it might be seen in a slightly different light-not as the truth, but as one chosen version of the truth. There are few greater rewards for the pedagogue than facilitating that process.

On the other hand, I am a realist, convinced beyond reasonable doubt that the educational, professional, and personal risks of teaching rape are substantial and unavoidable. ${ }^{70} I$ don't know if I avoided disaster because I was fortunate, skilled, or both. I have no confidence that a different group of students will refrain from attacks and confrontations that exceed the bounds of decency, fairness, and respect for diverse opinions-and it takes but a few to rock, and eventually tip, the boat. Should that occur, the educational objectives of an entire semester could be seriously frustrated, and all the students for whom I am responsible would be the losers.

Further, I have real fear that my reputation as a teacher could unfairly suffer irreparable harm that would be passed down through generations of students. ${ }^{71}$ There is no way to know the odds of such damage to my good name, but only solid reasons would induce me to take a sizable gamble.

I am also concerned about the unknown - and largely unknowable - personal costs imposed on students in the class. I would probably not refrain from teaching any subject because a small number of students might suffer personal anguish. To do so could preclude too many topics. But if a more than negligible number of women are put at risk of significant trauma from a study of the law of rape, only weighty reasons could persuade me to address the topic.

I am troubled by the possibility of emotional turmoil that should not be a necessary cost of my job. Of course, my position at the podium ensures that a certain amount of personal grief will come my way. Some will be deserved, some will be undeserved, and most will be unexpected. I would consider it foolish, however, to invite a predictable, cognizable amount of counterproductive and unnecessary mental and emotional distress. I do not relish the prospects of pleading good faith to students, explaining innocuous comments, defending against accusations of offenses perceived in the most innocent and wellintentioned remark, and being asked to apologize for slights felt, but not inflicted. If the teaching of rape means that I will find myself in such situations regularly,

70. Professor Erickson has suggested that it might help to begin teaching rape with a case about a heterosexual male rape victim. Erickson, Sex Bias, supra note 5, at 114. I suspect that rather than avoiding problems, such a tactic could lead to accusations of sexism. Women might well complain if even in this area, one in which women are typically victimized, the professor chose to begin by focusing on an atypical, male victim. Of course, an instructor could explain the reasons for beginning with such a case, but that path, too, could be perilous. Early on in my teaching career a colleague at UCLA proffered the sage advice: "Never apologize, never explain."

71. Of course, if my reputation began to suffer from my decision not to teach sexual assault, see Erickson, Sex Bias, supra note 5, at 114 (male professors have been accused by women students of sex bias because of their failures to teach rape), I would have yet another concern to weigh in the balance. 
I will probably eliminate the source of the problems by excluding the topic from my repertoire.

\section{This Essay-Aims and Hopes}

The object of writing this essay, however, was not to announce my bottom line. A personal reason for telling my tale and documenting my learning was a need to explore and explain my reactions in the hope of better understanding them. I also had some broader motives for relating my experiences.

One hope was to furnish a balanced foundation for sensible, well-considered conclusions by teachers considering whether to include rape in their first-year criminal law courses. Any instructor wishing to make an informed, intelligent decision should consider a number of competing concerns. ${ }^{72}$ I would suggest that no one enter the thicket with eyes closed, oblivious to the perils along the path. No one should choose to teach the subject simply because it is being urged upon him or her as the morally or politically proper thing to do. Nor should one refrain for the reason that "no one tells me what to teach." My conclusion is that the best one should hope for is a few minor scrapes and scratches. That was my experience at Michigan. The worst that awaits one is a painful and destructive educational fiasco. In between lie several possible outcomes.

I also wished to contribute to the incomplete debate over the question of teaching rape. The previous articles that have addressed the subject ${ }^{73}$ have been excellent stimulants for discussion and change. They have not, however, included a thoroughgoing consideration of the risks of teaching sexual assault. They have generally been written from the perspective of those whose primary concern is to eradicate teaching methods that might reflect or perpetuate sex bias in legal education. My hope was to provide some balance by proffering perspectives gained from my experiences in the trenches.

The one thing of which I am most convinced is that the subject of teaching rape, like the subject of rape, and, indeed, all difficult issues in our law and society, is far from as simple as it might first appear. ${ }^{74} \mathrm{I}$ can never return to the ignorant bliss in which the omission of rape went largely unquestioned by others and virtually unexamined by me. In the future, the presence of rape on my syllabus, or its absence, will be the result of a conscious choice rooted in an assessment of the best interests of all involved. For that, I am grateful to those who educated me during my time in Ann Arbor.

72. One's decision must inevitably take into account differences in academic milieus. I found more students whose attitudes seemed to create risks of dangerous confrontation and controversy at UCLA and Michigan, for example, than I have found at Iowa.

73. See supra notes 5 and 6.

74. It seems to me that public debate over the most controversial social issues is frequently characterized by gross oversimplification. I often wonder whether the human tendency to look for simple answers to complex questions impedes the search for constructive solutions. I am always exceedingly disappointed when lawyers, judges, or scholars fall prey to the same tendency. 